\title{
Histopathological findings in the cryptorchid testes of stallions
}

\author{
Heike Aupperle1, Kerstin Gerlach², C.P. Bartmann³, Sabine Beerhenke ${ }^{4}$ and H.-A. Schoon ${ }^{1}$ \\ 1 Institut für Veterinär-Pathologie, Universität Leipzig, Deutschland; ${ }^{2}$ Chirurgische Tierklinik, Universität Leipzig, Deutschland \\ ${ }^{3}$ Klinik für Pferde, Tierärztliche Hochschule Hannover, Deutschland; ${ }^{4}$ Tierklinik Vierhöfen, Deutschland
}

\begin{abstract}
Summary
Abdominal, inguinal and scrotal testes from 53 horses differing in age were examined by light microscopy including immunohistochemical techniques. Spermatogenesis of scrotal testes (controls) starts at the age of 1.5-2 years. By contrast, the development of cryptorchid testes occurs later at the age of 2-3 years. The degenerative alterations affecting the seminiferous tubules are more distinct in abdominal than in inguinal cryptorchidism. Additionally the differentiation of the peritubular and intertubular cells is retarded and disturbed in cryptorchid testes resulting in a deviating expression pattern of vimentin, desmin and $\alpha$-actin. Angiosclerosis in equine testes is a frequent age-related finding and is not associated to the location of the affected testes.

Four cases of "testicular regression syndrome" and two cases of an exclusive descent of the epididymis are reported. One case of a metastasising seminoma was diagnosed in a unilateral abdominal testis. The findings presented in this study show the possible complexity of alterations in cryptorchidism and, with a view to surgical success, the importance of detailed histopathological investigation of „abnormal“ tissues removed during castration.
\end{abstract}

Keywords: $\quad$ equine, cryptorchidism, seminoma, immunohistochemistry

\begin{abstract}
Histopathologische Befunde im kryptorchiden Hoden des Hengstes
Abdominale, inguinale und skrotale Hoden von 53 Pferden wurden histomorphologisch und immunhistologisch untersucht. Im skrotal gelegenen Hoden setzt die Spermiogenese im Alter von 1,5-2 Jahren ein, während die Differenzierung im kryptorchiden Hoden, zeitlich versetzt, im Alter von 2-3 Jahren beginnt. Die degenerativen Alterationen des Keimepithels sind bei abdominalem Kryptorchismus deutlicher ausgeprägt als im inguinal gelegenen Hoden. Darüber hinaus ist die Differenzierung der peritubulären und intertubulären Zellen verzögert und gestört. Dies kommt in einem veränderten Expressionsmuster der Filamente Vimentin, Desmin und $\alpha$-Aktin zum Ausdruck. Das Auftreten der häufig nachweisbaren Angiopathien im equinen Hoden ist altersassoziert aber unabhängig von der Lage des Hodens.

Weiterhin werden vier Fälle des sog. „testikulären Regressions Syndroms“ und zwei Fälle eines isolierten Nebenhodenabstiegs beschrieben. Bei einem Hengst konnte ein metastasierendes Seminom, ausgehend von einem abdominalen Hoden nachgewiesen werden. Die dargestellten Resultate verdeutlichen die Vielfalt möglicher Befunde im kryptorchiden Hoden sowie die Notwendigkeit einer gezielten histopathologischen Untersuchung jedes bei der Kastration entfernten anatomisch nicht zweifelsfrei zu identifizierendem Gewebes, um den Erfolg des operativen Eingriffes im Rahmen der Bedingungen des eingegangenen Werkvertrages zweifelsfrei sicherzustellen.
\end{abstract}

Schlüsselwörter: Pferd, Kryptorchismus, Seminom, Immunhistologie

\section{Introduction}

Nonpalpable testis in the horse is a clinical symptom belonging to a heterogeneous group of diseases revealing absent testes, cryptorchid testes, and clinically undetected testicular remnants located in the inguinal channel or the abdomen.

Cryptorchidism is defined as a unilateral or bilateral developmental defect characterised by a failure of the testis to descend into the scrotum. In some cases only the epididymis descends through the internal inguinal ring leaving the testis in an abdominal position. The etiology of a certain case of cryptorchidism remains obscure although various dispositions, either single or together, are discussed. Mechanical factors such as fibrous bands or adhesions are involved in unilateral cryptorchidism. In bilateral cryptorchidism an endocrine mediated etiology is more likely (Bergin et al., 1970). It has been reported that cryptorchidism causes alterations of functional maturation in the testes of different species (Hedinger, 1982; Arighi et al., 1987). But until now no results correlating the degenerative testicular chan- ges in equine cryptorchidism with the testicular position and the age of the affected animals are available.

The aim of the present study was to provide and to record the histomorphological and immunohistochemical variations between scrotal, inguinal and abdominal testes of stallions. Our investigations comprised the expression of the cytoskeletal filaments vimentin, desmin, and $\alpha$-smooth muscle actin. These have been established as markers for cell differentiation and it is generally accepted that vimentin is found in cells of mesenchymal origin, desmin in smooth and striated muscle and $\alpha$-actin in smooth muscle cells. However, an increasing number of reports indicates the phenomenon of a physiological coexpression of different filaments during embryonic development. Notwithstanding this coexpression indicates pathological processes in various organs.

Additionally, some cases of testicular malformations and maldescensus - of clinical importance in the stallion - will be described and discussed. 


\section{Material and methods}

108 testes from 53 horses at the age of one week to 22 years were collected at castration or necropsy (Tab. 1). Bilateral scrotal testes from 30 stallions served as controls. In 20 horses unilateral cryptorchidism was diagnosed and the contralateral testis was available in 17 cases, too. Additionally, testes from three stallions suffering from bilateral cryptorchidism (inguinal=2, abdominal=1) were included. In six further cases macroscopically untypical shaped tissue was found unilaterally in the scrotum $(n=3)$, inguinal $(n=1)$ or abdominal $(n=2)$ and sent to our Institute for detailed histopathological diagnosis.

Tab. 1: Age of the stallions and position of the investigated testes Alter der Hengste und Lage der untersuchten Hoden

\begin{tabular}{|c|c|c|c|c|c|c|}
\hline $\begin{array}{c}\text { Age } \\
\text { years }\end{array}$ & \multicolumn{2}{|c|}{$\begin{array}{c}\text { scrotal testes } \\
(\mathbf{n}=77) \\
\text { left }\end{array}$} & \multicolumn{2}{|c|}{$\begin{array}{c}\text { inguinal testes } \\
(\mathbf{n}=\mathbf{2 0})\end{array}$} & \multicolumn{2}{|c|}{$\begin{array}{c}\text { abdominal testes } \\
(\mathbf{n}=11)\end{array}$} \\
\hline$<1$ & 14 & 16 & 4 & 0 & 1 & 2 \\
\hline 2 & 11 & 13 & 5 & 4 & 1 & 0 \\
\hline $3-6$ & 6 & 7 & 3 & 3 & 1 & 3 \\
\hline $7-22$ & 5 & 5 & 1 & 0 & 1 & 2 \\
\hline
\end{tabular}

Specimens were obtained from epididymidal, medial and abepididymal areas of each testis, fixed in $4 \%$ formaldehyde and routinely embedded in paraplast. The sections were stained with $\mathrm{H}$.-E. and Picro-Sirius Red stain.

The expression of the intermediate filaments desmin and vimentin, and the microfilament $\alpha$-smooth muscle actin was detected by immunohistochemical techniques (PAP) using commercially available monoclonal interspecies crossreacting antibodies (Dako Diagnostika, Hamburg, Germany).

\section{Results}

\section{Development of scrotal testes}

\section{Histology}

During the first year of life testes contain small solid seminiferous tubules lying within a loose undifferentiated connective tissue with numerous vessels. The tubular epithelium consists of one or two layers of pre-spermatogonia and pre-Sertoli cells. The interstitial tissue can be divided into the intertubular cells and one layer of peritubular cells, surrounding the seminiferous tubules. In numerous interstitial macrophages yellowish-brown pigment is evident. The veins of the tunica albuginea and the parenchyma show a moderate panelastofibrosis (Fig. 1) while the arteries are not affected.

During the pubertal period (1-2 years of age) seminiferous tubules of scrotal testes start to develop their lumina according to the rising tubular diameter. Pre-spermatogonia differentiate into A- and B-spermatogonia and spermatogenesis begins. The pre-Sertoli cells differentiate into Sertoli cells, and Leydig cells are observed. Interstitial pigment disappears and the number of interstitial vessels decreases.

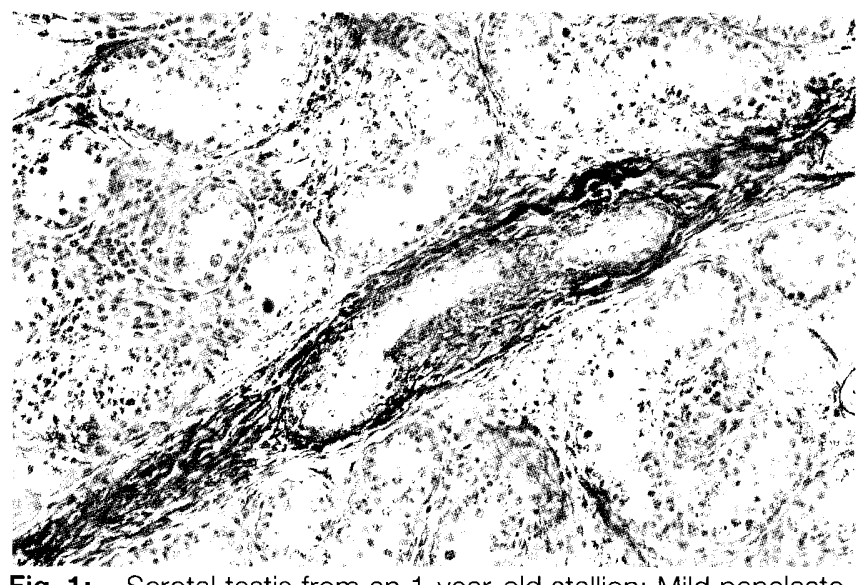

Fig. 1: Scrotal testis from an 1-year-old stallion: Mild panelastofibrosis affecting a venule. The parenchyma consists of immature seminiferous tubules and yellowish pigment occurs in interstitial macrophages. (Picro-Sirius Red stain, magnification $62.5 \mathrm{x}$ )

Skrotaler Hoden eines einjährigen Hengstes: Geringgradige Panelastofibrose einer Venule. Das Parenchym besteht aus unreifen Hodentubuli und in den interstitiellen Makrophagen ist gelbliches Pigment nachweisbar. (Pikrosirius-rot Färbung, Gerätevergrößerung 62,5x)

In stallions older than two years tubules show all stages of the seminiferous epithelial cycle. The tubules are surrounded by one or two layers of peritubular cells. The interstitium consists of a few fibroblast-like intertubular cells, numerous Leydig cells and a few vessels. Leydig cells of stallions older than six years often contain a yellowish-brown granular pigment.

Between the 2nd and 6th year of life testicular angiosclerosis is not prominent. In stallions older than six years, the

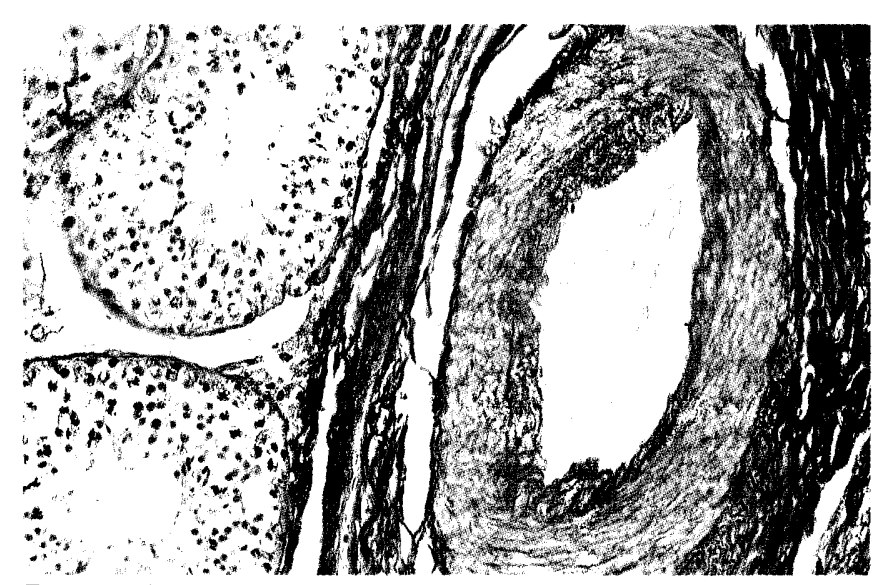

Fig. 2: Scrotal testis from a 10-year-old stallion: Moderate fibrosis of intima and media affecting an arteria of the tunica albuginea. Seminiferous tubules show signs of an active spermiogenesis. (Picro-Sirius Red stain, magnification $62.5 \mathrm{x})$

Skrotaler Hoden eines 10jährigen Hengstes: Mittelgradige Fibrose der Intima und Media einer Arterie in der Tunica albuginea. Die Hodentubuli weisen eine aktive Spermiogenese auf. (Pikrosirius-rot Färbung, Gerätevergrößerung 62,5x) 
vessels of the tunica albuginea and the parenchyma often show moderate signs of fibrosis affecting the arterial intima and media (Fig. 2) and the veins are affected by a mild perielastosis. In five cases a moderate lymphoplasmacellular perivasculitis and vasculitis of the arteries in the tunica albuginea occurs.

Immunohistochemistry

Vimentin is present in the cytoplasm of vascular smooth muscle cells, endothelia, Leydig cells, interstitial and peritubular cells, as well as in immature and mature Sertoli cells, but it is absent in the germ cell population of immature and mature testes (Fig. 3).

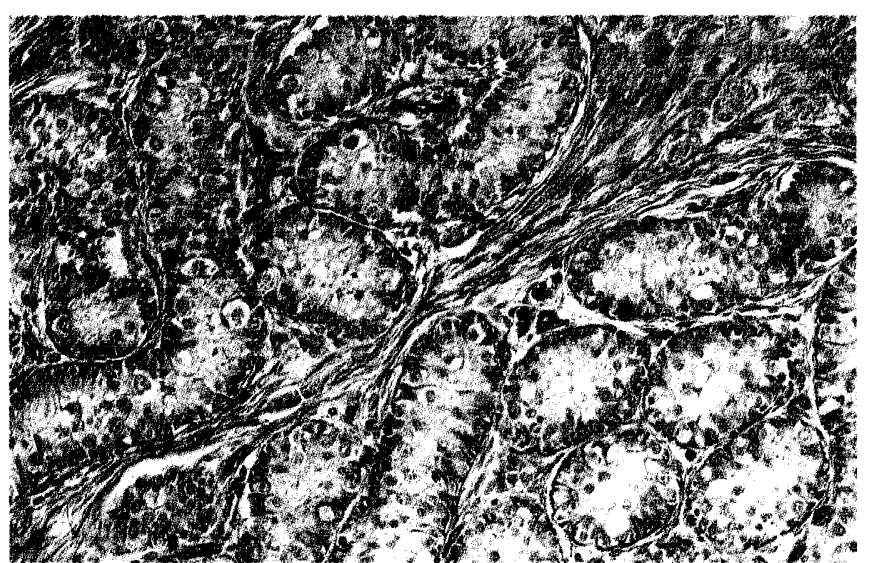

Fig. 3: Scrotal testis from an 1-year-old stallion: Vimentin expression is obvious in Sertoli cells, in intertubular and peritubular cells as well as in the vascular endothelium. The germinal cells of the immature solid seminiferous tubules are not labelled. (Immunohistochemistry, vimentin, Nomarski-interference-contrast, magnification 62.5x)

Skrotaler Hoden eines einjährigen Hengstes: Eine Expression von Vimentin ist in den Sertolizellen, den intertubulären und peritubulären Zellen sowie im Gefäßendothel nachweisbar. Die Keimzellen in den unreifen Tubuli reagieren jedoch negativ. (Immunhistologie, Vimentin, Nomarski-Interferenz-Kontrast, Gerätevergrößerung 62,5x)

Immunoreaction to $\alpha$-actin is found intracytoplasmatically in vascular smooth muscle cells, peritubular cells and intertubular cells in prepubertal testes. In the testis of adult stallions immunolabelling of the intertubular cells is absent (Fig. 4).

Expression of desmin in the testes of prepubertal stallions is restricted to the cytoplasm of vascular smooth muscle cells. In the testis of adult stallions desmin is additionally localised in the peritubular cells (Tab. 2).

\section{Development of cryptorchid testes}

In stallions younger than one year the left lateral cryptorchidism predominates. In the adult stallion left and right lateral cryptorchidism occurs with equal frequency. The cryptorchid testes of adult stallions are smaller than the scrotal testes and the cut surface shows a peculiar yellowishbrown discoloration until the age of three years. During the first 12 months of life, no histologically detectable differences can be found between cryptorchid and normal testes.
But in cryptorchid testes the beginning of differentiation is impaired until the age of 2-3 years.

In unilateral cryptorchidism no variations are detected between the contralateral scrotal testis and the bilateral scrotal controls.

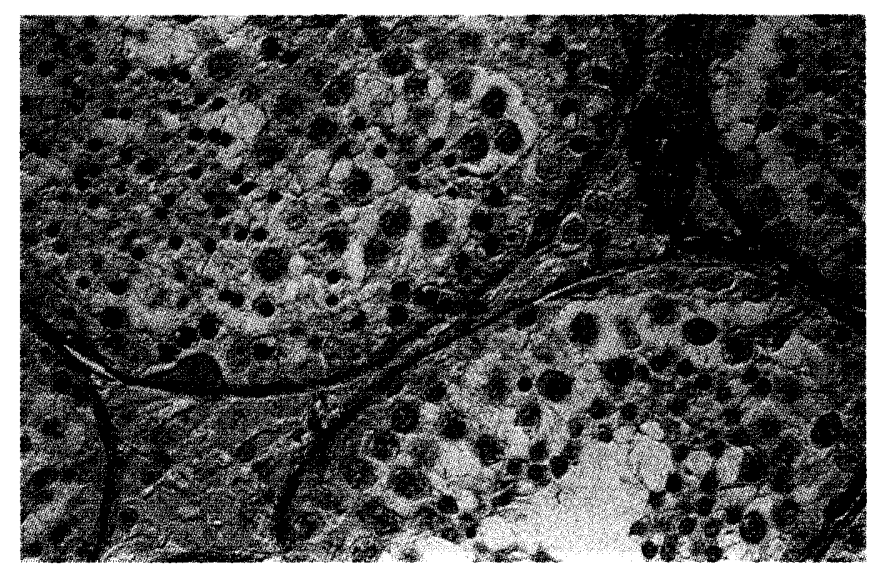

Fig. 4: Scrotal testis from a 10-year-old stallion: The tubules reveal physiological active seminiferous epithelia. Expression of $\alpha$-actin occurs in the peritubular cells and the vascular smooth muscle cells. Leydig cells and intertubular cells are not labelled. (Immunohistochemistry, $\alpha$-actin, Nomarski-interference-contrast, magnification $62.5 x)$

Skrotaler Hoden eines 10jährigen Hengstes: Die Hodentubuli zeigen eine aktive Spermiogenese. In den peritubulären Zellen und den glatten Muskelzellen der Gefäße ist $\alpha$-Aktin nachweisbar. Die Leydigzellen und die intertubulären Zellen reagieren negativ. (Immunhistologie, $\alpha$-Aktin, Nomarski-Interferenz-Kontrast, Gerätevergrößerung $62,5 x$ )

Inguinal testes after onset of differentiation

\section{Histology}

In stallions older than two years, the testes show three different areas:

1. In the periphery of the testis immature seminiferous tubules and interstitial cells dominate.

2. Adjacent is an intermediate zone showing the first signs of differentiation characterised by tubules containing Aand B-spermatogonia, spermatocytes I and Sertoli cells, and by interstitial Leydig cells.

3. In the centre of the testis the seminiferous tubules are dilated and lined by vacuolated Sertoli cells and very few A- and B-spermatogonia. Primary spermatocytes are not observed. Leydig cells show no signs of degeneration and compared with the scrotal testis the intertubular connective tissue and the number of vessels are slightly increased.

In stallions older than four years the germinal epithelium in general is nearly completely absent and the tubules are predominantly lined by Sertoli cells („Sertoli-cell-only“ syndrome). Leydig cells do not show any signs of degeneration. Mild intimafibroelastosis is observed in the arteries of the tunica albuginea and in the testicular parenchyma in stallions older than 4 years. 
Immunohistochemistry

The expression pattern of vimentin and the immunohistochemical labelling of the vessels corresponds with the findings described in the normal testes of prepubertal and adult stallions.

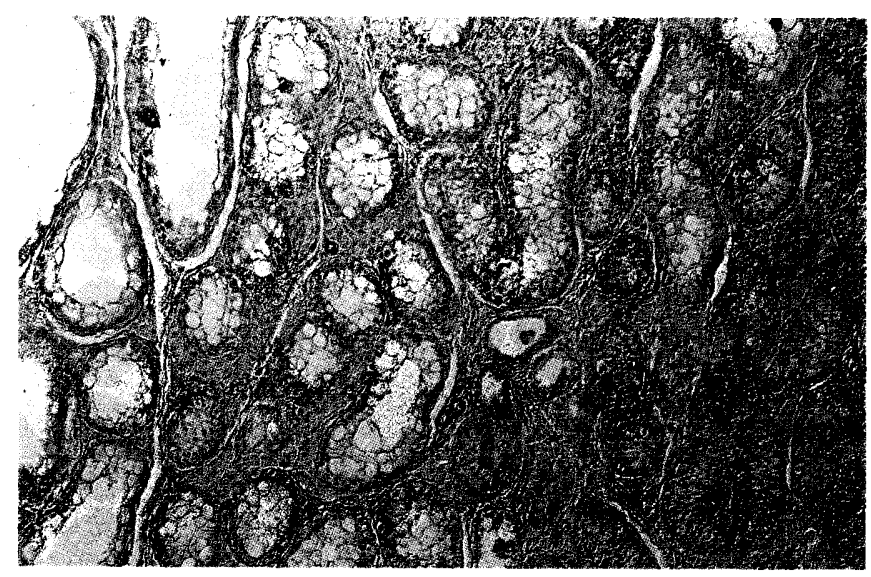

Fig. 5: Inguinal testis from a 2-year-old stallion: Sertoli cells in solid tubules showing first signs of differentiation express desmin. The dilated tubules in the centre of the testis are lined by a one-layered epithelium and vacuolated Sertoli cells without an expression of desmin. The peritubular cells and the vascular smooth muscle cells are labelled by desmin in both areas. (Immunohistochemistry, desmin, Nomarski-interference-contrast, magnification $31.25 x)$

Inguinaler Hoden eines 2-jährigen Hengstes: Die Sertolizellen in den soliden Tubuli mit ersten Anzeichen einer Differenzierung, exprimieren Desmin. Die dilatierten Tubuli im Zentrum des Hodens werden von einem einreihigen Epithel mit vakuolisierten Sertolizellen, die keine Desminexpression zeigen, ausgekleidet. Die peritubulären Zellen und die glatten Muskelzellen der Gefäße reagieren in beiden Arealen positiv. (Immunhistologie, Desmin, Nomarski-Interferenz-Kontrast, Gerätevergrößerung $31,25 x$ )

Tab. 2: Expression of vimentin, desmin and $\alpha$-actin in normal and cryptorchid testes

Expression von Vimentin, Desmin und $\alpha$-Aktin in normalen und kryptorchiden Hoden

\begin{tabular}{|c|l|c|c|c|}
\hline & & vimentin & desmin & $\alpha$-actin \\
\hline prepubertal & Sertoli cells & + & - & - \\
testes & intertubular cells & + & - & + \\
& peritubular cells & + & - & + \\
\hline adult & Sertoli cells & + & - & - \\
scrotal testes & intertubular cells & + & - & - \\
& peritubular cells & + & + & + \\
\hline adult & Sertoli cells & + & + & - \\
inguinal testes & intertubular cells & + & - & + \\
& peritubular cells & + & + & + \\
\hline adult & Sertoli cells & + & - & - \\
abdominal testes & intertubular cells & + & - & - \\
& peritubular cells & + & - & - \\
\hline
\end{tabular}

A coexpression of vimentin and desmin exclusively occurs in the Sertoli cells of the intermediate zone of differentiation in 2-3-year-old stallions (Fig. 5). Sertoli cells in stallions older than three years are only labelled by vimentin.

While immunoreaction to $\alpha$-actin in the intertubular cells vanishes completely with the onset of puberty in the scrotal testis, it is present in the inguinal testis (Tab. 2).

\section{Abdominal testes after onset of differentiation}

\section{Histology}

As in inguinal cryptorchidism development of abdominal testes is retarded until the age of two or three years. Seminiferous tubules show signs of growth, development and synchronous degeneration accompanied with dilated lumina, hydropic vacuolation of Sertoli cells and a lost of spermatogonia. These lesions show no zonal arrangement as in inguinal testes, but they are distributed diffusely. Leydig cells are obvious and the intertubular cells and the number of vessels are increased compared with the scrotal testes. At the age of four years only dilated seminiferous tubules, lined by an one-layered epithelium showing „Sertoli-cell-only" morphology occur. Small amounts of a yellowish pigment appear in the Leydig cells (Fig. 6).

In stallions older than four years a moderate intimafibroelastosis of arteries affecting those of the parenchyma and the tunica albuginea is observed.

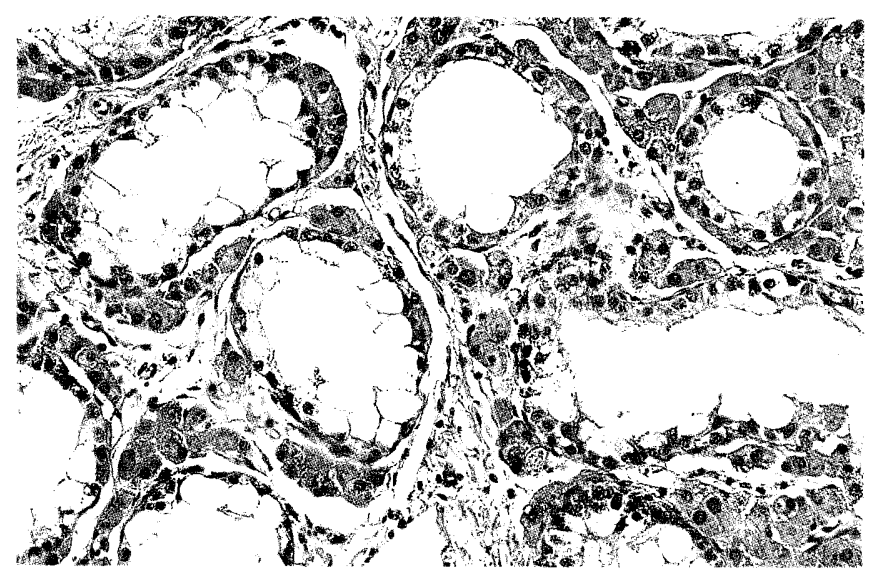

Fig. 6: Abdominal testis from a 5-year-old stallion: Dilated seminiferous tubules are lined by an one-layered epithelium with vacuolated Sertoli cells. Numerous Leydig cells contain intracytoplasmatic pigment. ( $\mathrm{H}$.-E. staining, magnification $62.5 \mathrm{x}$ )

Abdominaler Hoden eines 5-jährigen Hengstes: Die dila tierten Hodentubuli werden von einem einreihigen Keimepithel mit vakuolisierten Sertolizellen ausgekleidet. Zahlreiche Leydigzellen enthalten ein gelbliches Pigment. (H.-E. Färbung, Gerätevergrößerung 62,5x)

Immunohistochemistry

The expression of vimentin and the immunohistochemical labelling of the vessels corresponds with the findings described in the normal immature and mature testes.

In contrast to the inguinal testes no desmin expression in Sertoli cells can be detected in the abdominal testes. Addi- 
tionally the desmin expression of the peritubular cells, observed in adult scrotal and inguinal testes, is lacking in the abdominal testes (Tab. 2).

A strong $\alpha$-actin immunostaining is present in the peritubular cells, similar to the results in normal testes of the adult stallions and in contrast to the findings in inguinal cryptorchidism.

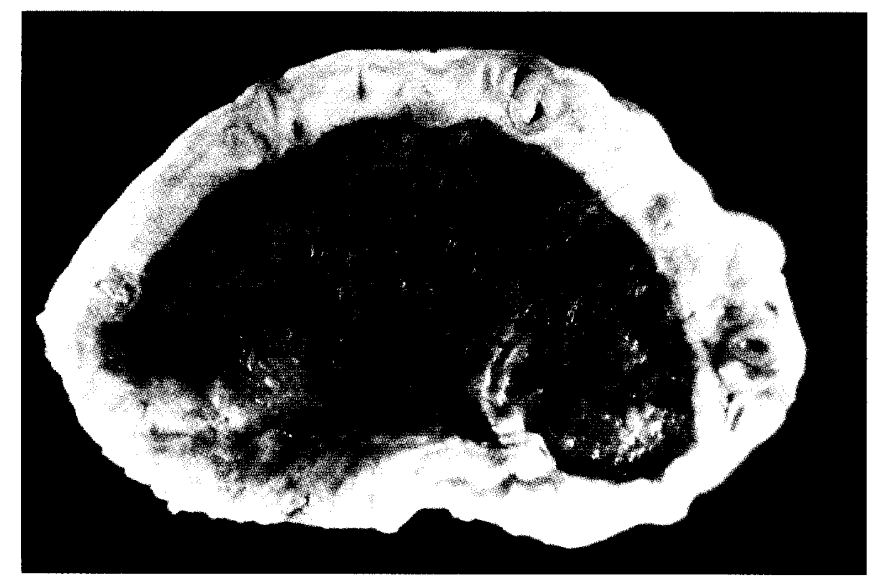

Fig. 7a: Tissue from the inguinal canal from a 7-year-old stallion („Testicular regression syndrome?"): Macroscopically untypical "testicular"-shaped tissue with a thick fibrous capsule and firm brown cut surface.

Gewebe aus dem Inguinalspalt eines 7-jährigen Hengstes (,Testikuläres Regressionssyndrom?"): Makroskopisch „Hoden"-ähnliches Gewebe mit einer dicken bindegewebigen Kapsel und derber brauner Schnittfläche.

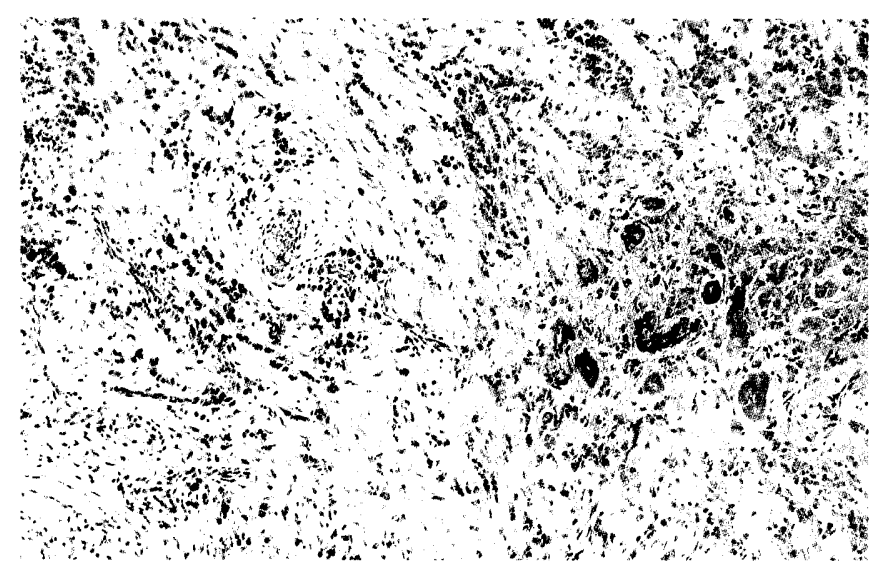

Fig. 7b: Fibrous connective tissue with hemosiderosis and dystrophic calcification and degeneration of tubular structures. (H.-E. staining, magnification $31.25 \mathrm{x}$ )

Fibröses Bindegewebe mit Hämosiderinablagerungen und dystrophischer Verkalkung und Degeneration tubulärer Strukturen. (H.-E.-Färbung, Gerätevergrößerung $31,25 x)$

\section{Exceptional cases}

Macroscopically untypical shaped fibrotic-like tissue was removed from 6 stallions during castration.

In two cases the histopathological investigation of the untypical scrotal tissue revealed exclusively epididymal parts. After stimulation tests and determination of plasma hormone levels in both stallions, the abdominal testes were re- moved during subsequent laparatomy. While no epididymal tissue was detectable neither macroscopically nor histopathologically, the findings of parenchymal differentiation correspond to the results described previously in stallions of the same age.

In four stallions atypical tissue components (Fig. 7a) were removed unilaterally from scrotal $(n=1)$, inguinal $(n=1)$ and abdominal $(n=2)$ positions. The histopathological investigation showed fibrous connective tissue, dystrophic microcalcification and hemosiderin deposits in all cases (Fig. 7b). In two specimens additional epididymal tissue but no seminiferous tubules were observed. In one case a few hyalinized and atrophic seminiferous tubules appeared and in the fourth one exclusively connective tissue was found.

In a 14-year-old stallion a metastasising seminoma occurred, originating from an abdominal testis. It weighted $4.5 \mathrm{~kg}$,

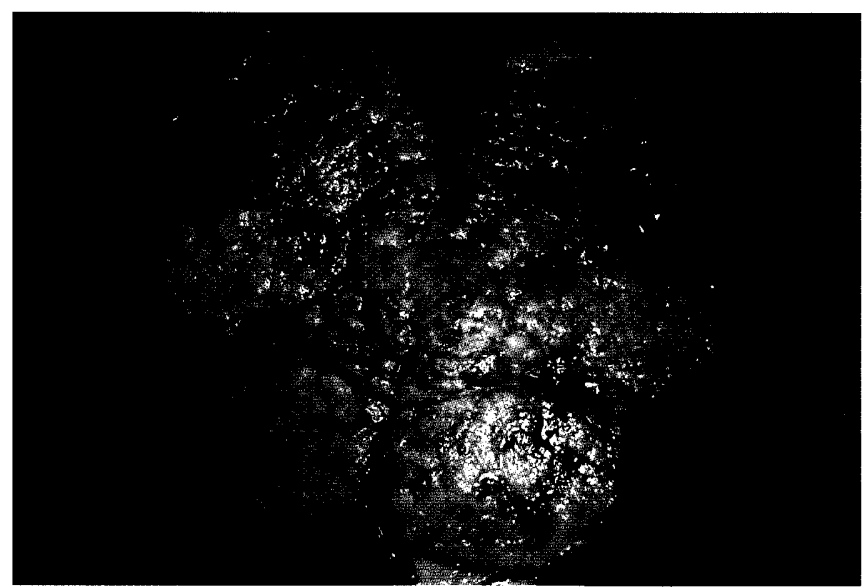

Fig. 8a: Seminoma in the abdominal testis from a 14-year-old stallion: Testis weighting $4.5 \mathrm{~kg}$, with a firm, multilobulated yellowish-brown cut surface and multifocal bleedings.

Seminom im abdominalen Hoden eines 14-jährigen Hengstes: 4,5 kg schwerer Hoden mit lobulierter gelblichbrauner Schnittfläche und multiplen Blutungen.

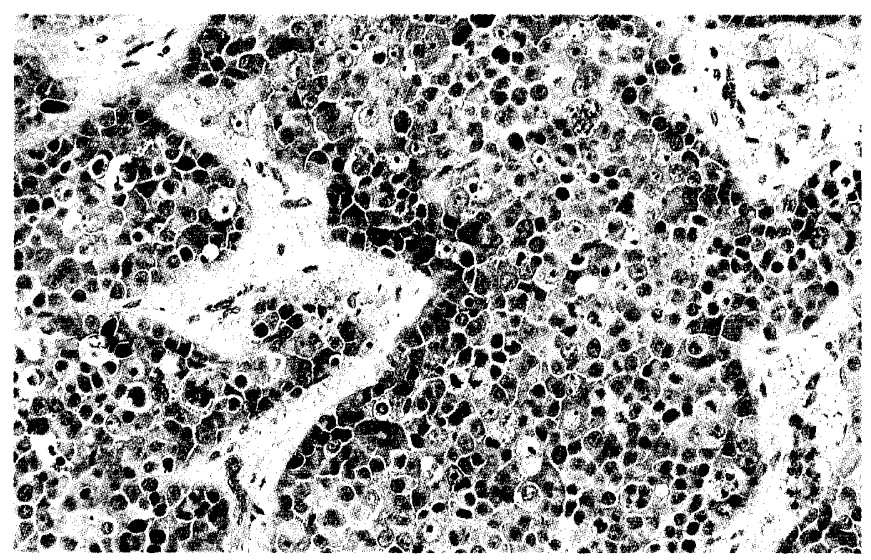

Fig. 8b: Tumour cells with round nuclei, prominent large nucleoli and abundant eosinophilic cytoplasm, typical and atypical mitoses. ( $H$.-E. staining, magnification $62.5 \mathrm{x}$ )

Tumourzellen mit runden Kernen, großen Nucleoli und deutlichem eosinophilem Zytoplasma, zahlreiche typische und atypische Mitosefiguren nachweisbar. (H.-E. Färbung, Gerätevergrößerung 62,5x) 
showed a firm yellowish-brown multilobulated cut surface (Fig. 8a) and voluminous metastases in the sublumbar lymph nodes, the adrenal glands and the mesentery. The tumour cells are characterised by round nuclei, prominent large nucleoli and an abundant eosinophilic cytoplasm. Typical and atypical mitotic figures are numerous (Fig. 8b).

\section{Discussion}

The histological findings of our investigations of scrotal testes of prepubertal and adult stallions correspond with the results described by Arighi et al. (1987). In accordance with Clemmons et al. (1995) we observed that the spermatogenesis in scrotal testes starts in 1.5-2 year-old horses. In agreement with Schulz (1996) we found pigment in macrophages in prepubertal stallions, and in Leydig cells from old stallions. Using special stainings, fluorescence microscopy and Transmission electron microscopy, Schulz (1996) identified the pigment in macrophages as ceroid and in Leydig cells as lipofuscin. As described by Kirby et al. (1985) no histomorphological variations between the bilateral scrotal testes and the contralateral scrotal testis in unilateral cryptorchidism were detected.

In stallions the physiological distribution pattern of the cytoskeletal elements in various testicular constituents has not been investigated to date. Our results correspond with the findings described in men (Martin et al., 1992). By contrast Steger and Wrobel (1994) reported that the desmin expression completely vanishes from peritubular cells during puberty in normal ovine testis.

Vascular alterations in the equine testes are described for the first time. No explanation could be found for the panelastofibrosis of veins in equine prepubertal testes, which seems to disappear with the onset of puberty. However, in the adult stallion angiosclerosis of the testis is assumed to be age-related. This is in contrast to the findings of Jensen et al. (1962), who reported that the incidence of angiosclerosis in the testes of rams is independent of age.

In the present study, no differences between cryptorchid and normal testes are detected during the prepubertal period. The predominance of left over right cryptorchidism may be explained by the relatively slower descent of the left testis (Bergin et al., 1970), resulting in a higher incidence of the diagnosis „left side cryptorchidism" in juveniles. This situation apparently rights itself during the following year of life with the retarded descent of the retained testis.

In the cryptorchid testes we investigated, the testicular development was arrested until the age of three years. The pathogenesis of the retarded testicular maturation remains unclear. Following the onset of differentiation the first signs of vacuolar degeneration in Sertoli cell were observed in cryptorchid testes. This may suggest that the germinal cells are damaged secondarily because of their close association with the Sertoli cells. We found that the lesions in the inguinal testes of stallions older than 2 years are more gradual compared with the abdominal testes and show a zonal arrangement of different findings. In normal testis maturati- on starts during puberty in the centre of the testis and a distinct zonal distribution of different stages has been described (Clemmons et al., 1995). The zonal differences of the histological findings in the inguinal testes are interpreted as physiological according to Clemmons et al. (1995), finally, however, resulting in inactivity rather than in the development of complete spermiogenesis. In abdominal testes alterations show a diffuse distribution pattern throughout the whole organ. This possibly reflects the effect of the higher temperature in the local environment of retained testis (Frankenhuis and Wensing, 1979). As described in previous studies (Al-Bagdadi et al., 1991; Arighi et al., 1987) spermatogenesis does not proceed beyond type A- or B-spermatogonia in the abdominal testis, or early primary spermatocytes in the inguinal testis, with a complete absence of spermatozoa, decreased spermatogenetic layers and decreased tubular diameter. At least the typical "Sertolicell-only" morphology can be observed in inguinal and abdominal testes of all animals older than four years. Histological alterations described in equine cryptorchidism are similar to the results in men (Hadziselimovic et al., 1987; Hedinger 1982), but ring tubules and Leydig cell degeneration, typical in men, have not been detected in the horse.

From the age of four years abdominal testes show signs of arteriosclerosis as they are observed in the scrotal testes of stallions older than six years. The complete effect of cryptorchidism upon vascular damage is unclear because inguinal testes of elder stallions have not been included in this investigation. Comparable studies dealing with vascular lesions in cryptorchidism are not available.

We used immunohistochemical techniques to detect intermediate filaments and microfilaments, which are known to be marker of the cellular differentiation (Stewart, 1990). While similar studies are available in humans (Martin et al., 1992; Maekawa et al., 1996), this is the first investigation in equine cryptorchidism.

Sertoli cells coexpressing vimentin and desmin occur exclusively in areas of early differentiation of inguinal testes. This coexpression has been described in human fetal testes, cryptorchidism and tumours (Rogatsch et al., 1996) but not in the normal testes of adult men (de Miguel et al., 1997).

We demonstrated that the differentiation of the peritubular cells in abdominal testes and of the intertubular tissue in inguinal testes is disturbed. Peritubular myoid cells serve as a part of the blood-testis-barrier and play a role in contractions of the seminiferous tubules to aid the transport of spermatozoa. Additionally it is known that they also take part in the regulation of spermatogenesis and the testicular function (Maekawa et al., 1996). The altered differentiation of interstitial cells in equine cryptorchid testes observed in this study might suggest that they are responsible for lesions of the Sertoli cells and therefore for the degeneration of the germinal cells as well. The disturbed differentiation of the peritubular cells in abdominal testes may result in a more rapid degeneration of the germinal epithelium. Altered differentiation of the intertubular and peritubular cells has also been reported in humans suffering from Klinefelter's syndrome (Martin et al., 1992). 
Various signs of disturbed development in cryptorchid testes have been demonstrated and it may become obvious why there is a higher incidence of testicular neoplasms in cryptorchid testes. Seminoma is the most common testicular tumour in the horse and, as in other species, it appears to bear a higher prevalence in cryptorchid animals. Although most seminoma are relatively benign in dogs, extensive metastasis to the abdominal viscera and lymph nodes have been reported in horses (Hunt et al., 1990; Smith et al., 1989). It appears that equine seminomas have a greater tendency to metastasise than those in the dog (McEntee, 1990).

Additionally we reported some exceptional cases of atypical tissue removed from scrotal, inguinal and abdominal positions. In two cases the - phylogenetically independent epididymis was found in the scrotum leaving the testis without epididymal tissue in an abdominal position, as previously reported by Bishop et al. (1966) and Bergin et al. (1970). These results show the importance of examination and identification of the tissue excised during castration to ensure that all parts have been removed.

In four other cases we investigated, the testicular tissue was replaced by fibrous and calcified connective tissue. These findings are similar with a phenomenon described as „testicular regression syndrome" or „vanishing testis", but a definite diagnosis could have only been made in combination with case history and accurate intraoperative clinical and pre- and postsurgical endocrinological control. These perisurgical examinations are an essential tool to exclude fibrous tissue resulting from previous surgery as well as remnants of the amputation stump of the spermatic cord. Parks et al. (1989) reported that eight out of nine cases of monorchidism in horses were caused by testicular degeneration and only one by testicular agenesia. Merry et al. (1997) and Grady et al. (1998) showed that in boys with nonpalpable testes, the incidence of vanishing testes is much higher than true congenital absence of testis including the vas deferens and the epididymis. Torsion or obstruction to testicular blood supply is believed to play the most important role in this "testicular regression syndrome“. The majority of cases of in utero testicular torsion causing vanishing testis occurs during the transinguinal migration.

\section{Literature}

Al-Bagdadi, P. Hoyt, P. Karns, G. Martin, M. Memon, R. McClure, D. McCoy and S. Shoemaker (1991): The morphology of abdominal and inguinal cryptorchid testes in stallions: a light and electron microscopic study. Int. J. Fertil., 36, 57-64

Arighi, M., A. Singh, W.T.K. Bosu and F.D. Horney (1987): Histology of the normal and retained equine testis. Acta anat., 129, 127-130

Bergin, W.C., H.T. Gier, G.B. Marion and J.R. Coffman (1970): A developmental concept of equine cryptorchism. Biol. Reprod., 3 , 82-92

Bishop, M.W.H., J.S.E. David and A. Messervy (1966): Cryptorchidism in the stallion. Proc. R. Soc. Med., 59, 769-760

Clemmons, A.J., D.L. Thompson and L. Johnson (1995): Local initiation of spermatogenesis in the horse. Biol. Reprod., 52, 1258-1267

Frankenhuis, M.T. and C.J.G. Wensing (1979): Induction of spermatogenesis in the naturally cryptorchid pig. Fertil. Steril., 31, 428-433
Grady, R.W., M.E. Mitchell and M.C. Carr (1998): Laparoscopic and histologic evaluation of the inguinal vanishing testis. Pediatr. Urol., 52, 866-869

Hadziselimovic, H., B. Herzog and M. Buser (1987): Development of cryptorchid testes. Eur. J. Pediatr., 146, Suppl. 2, 8-12

Hedinger, C.E. (1982): Histopathology of undescended testes. Eur. J. Pediatr., 139, 266-271

Hunt, R.J., W. Hay, C. Collatos and E. Welles (1990): Testicular seminoma associated with torsion of the spermatic cord in two cryptorchid stallions. JAVMA, 197, 1484-1486

Jensen, R., J.C. Flint, W.W. Brown and J.R. Collier (1962): Arteriosclerosis and phlebosclerosis in testes of sheep. Am. J. Vet. Res., 23, 480-488

Kirby, R.S., C.R. Chapple, S.P. Ward and C. Williams (1985): Is the scrotal testis normal in unilateral cryptorchidism? Brit. J. Urol., 57, 187-189

Maekawa, M., K. Kamimura and T. Nagano (1996): Peritubular myoid cells in the testis: their structure and function. Arch. Histol. Cytol., $59,1-13$

Martin, R. L. Santamaria, M. Nistal, B. Fraile and R. Paniagua (1992): The peritubular myofibroblasts in the testes from normal men and men with Klinefelter's syndrome. A quantitative, ultrastructural, and immunohistochemical study. J. Pathol., 168, 59-66

Mc Entee (1990): Reproductive pathology of domestic mammals. Academic press, San Diego, London, 286-290

Mendis-Handagama, SMLC, J.B. Kerr and D.M. de Kretser (1990): Experimental cryptorchidism in the adult mouse: I Qualitative and quantitative light microscopic morphology. J. Androl., 11, 539-547

Merry, C., B. Sweeney and P. Puri (1997): The vanishing testis: anatomical and histological findings. Eur. Urol., 31,65-67

de Miguel, M, F.R. Bethencourt, M.I. Arenas, B. Fraile and Ricardo Paniagua (1997): Intermediate filaments in the Sertoli cells of the ageing human testis. Virchows Arch., 431, 131-138

Miliarias, D., E. Vlahakis-Miliarias, D. Anagnostopoulos, G. Koutsoumis, G. Pergamalis and S. Miliaras (1997): Gross morphologic variations and histologic changes in cryptorchid testes. Pediatr. Surg. Int., 12, 158-162

Parks, A.H., E.A. Scott, J.E. Cox and J.A. Stick (1989): Monorchidism in the horse. Equine Vet. J., 21, 215-217

Rogatsch, H., D. Jezek, A. Hittmair, G. Mikuz and H. Feichtinger (1996): Expression of vimentin, cytokeratin, and desmin in Sertoli cells of human fetal, cryptorchid, and tumour-adjacent testicular tissue. Virchows Arch., 427, 497-502

Schulz, W. (1996): Morphologische und enzymhistochemische Aspekte der Spermatogenese bei Warmbluthengsten, Diss. vet. med., Tierärztliche Hochschule Hannover

Smith, B.L., L.D. Morton, J.P.Watkins, T.S. Taylor and R.W. Storts (1989): Malignant seminoma in a cryptorchid stallion. JAVMA, 195, $775-776$

Steger, K and K.-H. Wrobel (1994): Immunohistochemical demonstration of cytoskeletal proteins in the ovine testis during postnatal development. Anat. Embryol., 189, 521-530

Stewart, M. (1990): Intermediate filaments: structure assembly and molecular interactions. Curr. Opin. Cell Biol., 2, 91-100

Dr. Heike Aupperle

Prof. Dr. H.-A. Schoon

Institut für Veterinär-Pathologie

Universität Leipzig

An den Tierkliniken 33

D 04103 Leipzig

Tel.: 00493419738277

Fax: 00493419738299 